\title{
CAPTURING THE 'PIONEERING MINDS' VIA HUMAN CAPITAL: THE IMPACT ON INNOVATIVE PERFORMANCE OF MALAYSIAN SMES
}

\author{
Hasliza Abdul Halim ${ }^{1 *}$, Noor Hazlina Ahmad ${ }^{1}$, T. Ramayah ${ }^{1,2}$ and \\ Seyedeh Khadijeh Taghizadeh ${ }^{1}$
}

${ }^{1}$ School of Management, Universiti Sains Malaysia, 11800 Pulau Pinang, Malaysia

${ }^{2}$ UTM International Business School (UTM-IBS), Universiti Teknologi Malaysia, 54100 Kuala Lumpur, Malaysia

${ }^{3}$ Center of Social Innovation, Universiti Teknologi PETRONAS, 32610 Seri Iskandar, Perak, Malaysia

*Corresponding author: haslizahalim@usm.my

Published online: 30 December 2016

To cite this article: Hasliza Abdul Halim, Noor Hazlina Ahmad, Ramayah, T., and Taghizadeh, S.K. (2016). Capturing the 'pioneering minds' via human capital: The impact on innovative performance of Malaysian SMEs. Asian Academy of Management Journal, 21(Supp. 1), 105-126. http://dx.doi.org/10.21315/aamj2016.21.supp.1.5

To link to this article: http://dx.doi.org/10.21315/aamj2016.21.supp.1.5

\begin{abstract}
To cultivate "pioneering minds" is extremely important especially in the effort to shift Malaysia towards innovation-centered economy. The Malaysian government is confident of achieving the target provided that the human capital is leveraged in ensuring innovation at the highest level particularly among Small and Medium Enterprises (SMEs). Nevertheless, only few studies have considered human capital as a factor that mediates the effects of other variables on innovation. Therefore, this paper aims at investigating on how human capital dimensions namely uniqueness, value and pro-activeness will be leveraged by pro-innovativeness organisational architecture dimensions that is allocation for free time, work discretion, rewards, and tolerance for risk taking in order to achieve innovative performance. A structured study instrument was used for data collection purpose. A total of 1000 active SMEs were selected via simple random sampling from Malaysia Small and Medium Enterprises Directory 2011/12. A total of 263 SMEs responded to the questionnaire. However, a total of 262 usable questionnaires were thus secured for analysis. The analysis was then conducted via Partial Least Squares (PLS) structural equation modeling (SEM). The results showed several interesting findings: (a) rewards has an influence on the uniqueness, value and pro-activeness of human capital; (b) tolerance towards risk taking has an influence on human capital (uniqueness, value and pro-activeness; (c) uniqueness
\end{abstract}


of human capital has an influence on innovative performance and (d) uniqueness of human capital mediated the relationship between tolerance for risk taking and innovative performance. The findings suggest that SMEs should put more focus on the reward system and tolerance for risk taking in order to encourage and enhance the 'pioneering mind' which in turn may increase innovative performance of SMEs.

Keywords: pro-innovativeness organisation architecture, innovative human capital, innovative performance, SMEs, and Malaysia

\section{INTRODUCTION}

In the last five years, Malaysia has encountered many challenges from a global economic slowdown, increase in market integration, stiff competition and dynamism in the economy. With this current scenario, the Malaysian government has introduced the Eleventh Malaysia Plan from 2016-2020 as a critical step in the roadmap to turn into an advanced nation that is inclusive and sustainable (Eleventh Malaysia Plan, 2016-2020). Malaysian Government believes that the Eleventh Malaysian Plan is a significant continuation of Government Transformation Programme and the Economic Transformation Programme, underpinned by the Tenth Malaysia Plan. Moving forward, productivity and innovation will continue to be significant pillars of the Eleventh Plan in which Malaysia has put a lot of effort for Small and medium-sized enterprises (SMEs) to survive in the dynamic environment. SMEs are the engine of economic growth and employment in developing countries. This is because SMEs are recognised as the backbone to economic development and employment growth (Ramayah, Ling, Taghizadeh \& Rahman, 2016). In Malaysia, the SME sector has an important role in the supporting of industrial development (Saleh and Ndubisi, 2006; Yeoh, 2014). In 2015, SMEs in Malaysia comprised $97.3 \%$ of all business establishments and contributed about $33.1 \%$ of gross domestic product (GDP), $57.5 \%$ of total employment, and $19 \%$ of exports in the country (SMECorp, 2015). Therefore, considering the important role of SMEs, the Malaysian government continues to support the development of SME sector as a key national development strategy (Ramayah et al., 2016). In with this, to innovate successfully, SMEs need strategic innovation and business practices that facilitate innovativeness, creativity and risk-taking behaviours encouraged by a stable platform and cooperation networks supported by an effective institutional framework (Minh \& Hjortsø, 2015).

Malaysia government has moved towards a sustainable economy, and has shifted from the agricultural based economy to knowledge-based economy to innovationcentered economy where knowledge, "know-how" and innovativeness become the main drivers for economic growth (MOSTI, 2010). The knowledge-based 
and innovation centered economy provide the platform to sustain a rapid rate of economic growth and enhance international competitiveness among SMEs so as to achieve the objectives of Vision 2020. This agenda includes effort and continuous investment in human capital to enhance technical skills, proactiveness, creativity and innovativeness among SMEs. Malaysian government has taken various measures to provide assistance for SMEs to confront the challenges in the global economy. One of the approaches is that SMEs are given special focus as private sectors and the SMEs are expected to continue their significant role to help Malaysia become an advanced economy and inclusive nation. In this respect, Malaysian government instills the spirit of intrapreneurial among the employees to enhance productivity, innovativeness, and job performance. This approach is echoed in the Economic Transformation Programme Report in which Malaysia aims to transform its economy by strengthening and escalating the human capital development (National Economic Advisory, 2010). As clearly highlighted by the Prime Minister of Malaysia, Dato Seri Najib Tun Razak, Malaysia aspires to reach the highest standards with regard to the skills, knowledge and abilities of its human capital as well as to inculcate entrepreneurial spirit among SMEs especially in the innovation-centered economy. SMEs is acknowledged as an important sector to inject investment and transform Malaysia into a developed nation by 2020.

Despite of these efforts by the Malaysian government, SMEs are not achieving high performance and this is evidenced by the SMEs contribution to GDP is only 32\% (SMEs Master Plan 2010-2020). To worsen the situation, Malaysia experienced a declining trend in the ranking of Global Competitiveness Index, from 21st place in year 2009 to 26th in year 2014 (World Economic Forum, 2015). This condition has given a worrying phenomenon for SMEs to survive. Apparently, in this situation SMEs need to intensify their business performance and competitiveness by enhancing their innovative capabilities particularly on human capital. Unfortunately, the concept of innovative human capital among the Malaysian SMEs is still in its infancy. Therefore, Malaysia needs to encourage "pioneering minds" among the human resources to be innovative, creative and proactive in order to move towards innovation-centered economy. Malaysia has to strengthen its capability to innovate, adapt and create indigenous technology, design, develop and market new products. An instrument to rectify this situation is to nurture "pioneering minds" in nurturing innovativeness and entrepreneurship spirit among Malaysia workforce to enhance productivity and performance.

In line with the Malaysian government aspiration to transform its economy by fostering innovative performance via innovative human capital, research on innovation and human capital warrants significant attention. The gap in this study is identified in which previous studies have examined the relationship between 
innovation and human capital (Alegre, Lapiedra \& Chiva, 2006), however, despite the role that human capital is assumed to have on innovation, very limited studies have considered the factors that could nurture the "pioneering minds" that is to capture on innovative human capital that are able to drive innovative performance. Based on the current scenario explained above, coupled with previous literatures, there are almost next to none effort has been made to examine human capital as the mediator between pro-innovativeness architecture and innovative human capital. Consequently it is imperative to understand the factors associated with innovative human capital which in turn could improve innovative capability and organisational performance. In this respect, the "pioneering minds" could be achieved by leveraging the innovation of human capital through pro-innovativeness organisational structure.

Importantly, it would obviously be interesting (and potentially beneficial) to know: (i) how innovative human capital will be influenced by pro-innovativeness organisational structure; (ii) the impact on innovative performance; and iii) how innovative human capital mediates the relationship between pro-innovativeness organisational structure and innovative performance. The remainder of this paper is organised as follows. The next section presents a discussion of the theoretical framework of the study, including the generation of hypotheses. The paper then describes the methodology of the empirical study. The results of the study are then presented and discussed. The paper concludes with a summary of the major findings and implications of the study.

\section{THEORETICAL FRAMEWORK AND HYPOTHESES}

To develop the research hypotheses outlined below, this study utilises both: (i) the resource-based view (RBV) of the organisation and ii) human capital theory RBV focuses on the value, rareness, non-substitutability, and inimitability of organisational resources, including human capital. RBV mainly outlines the required focal points (e.g. resources) of the firms and what can be done with such resources in order to be in better position than others in the market (Wernerfelt, 2014). It has been argued that in capitalising resources, an organisation can dominate and achieve a high level of performance (Barney, 1991). Organisation resources are converted to capabilities which would have influence on competitive advantage (Barney, 1991). Scholars have argued that firm's resources such as physical, human, and organisational can be used to implement value-creating strategies (Henri, 2006; Teece, Pisano \& Shuen, 1997). Through the implementation of the value creating strategy firm can be in a better competitive position (Barney, 1991). Several key capabilities were identified in RBV theory, such as technical 
know-how, reputation, brand, awareness, the ability of managers to work together, and particularly patents and trademarks (Fahy, 2000). In this study RBV is used to understand further how human capital could enhance innovative performance by understanding further the dimensions of pro-innovativeness organisational architecture dimensions such as allocation for free time, work discretion, rewards, and tolerance for risk taking.

In a similar vein, human capital theory suggests that individuals or groups who have greater levels of knowledge, skills, and other competencies will achieve greater performance outcomes than those who own lower levels (Ployhart and Moliterno, 2011). Common measures of human capital include level of education, work experience, upbringing by entrepreneurial parents, and other life experiences (Martin, McNally \& Kay, 2013). This study focuses on human capital comprises uniqueness, value and proactiveness which refers to the stock of competences, expertise, knowledge, and connections that a firm's employees gain through education and experience. This situation may enhance innovative performance of the organisations.

Organisational architecture focuses on the organisational behaviour aligning with structure, process, and design. According to Miciunas (2003) organisational architecture gives accents in motivating people to execute their work in innovative ways. An organisation-wide entrepreneurial spirit to cope with and benefit from rapidly changing market place conditions would be possible if a suitable internal support climate is established, where entrepreneurs engage in opportunity-seeking entrepreneurial behaviours (Abdul Halim, Ahmad, Ramayah \& Taghizadeh, 2014; Jeong, Pae \& Zhou, 2006). However, achieving performance and benefit from the market depend on providing suitable internal support climate throughout the organisation, where entrepreneurs engage in opportunity-seeking entrepreneurial behaviour (Jeong et al., 2006). In order to establish a suitable internal support climate for entrepreneurship, researchers believe that several organisational arrangement and managerial tools are crucial to be taken into account namely allocation of free time, work discretion, rewards, and tolerance for risk taking (Alpkan, Bulut, Gunday, Ulusoy \& Kilic, 2010; Hornsby, Kuratko, Holt \& Wales, 2013; Kuratko, Ireland, Covin \& Hornsby, 2005). It is expected that in such suitable organisational milieu, employees would develop state of pro-innovativeness (Alpkan et al., 2010).

It has been stressed that organisation should capitalize on their employees' ability to innovate in order to transform the organisation to be more competitive (De Jong \& Den Hartog, 2007). Therefore, the workforce could play a vital role in the innovation process by demonstrating the idea-generation behaviour via efforts such as persuading or selling ideas to others and devoting to developing testing 
and commercialising the ideas. Human capital in general is referred to knowledge, skills and abilities featured in the individuals (Subramaniam \& Youndt, 2005). On the contrary, Lepak and Snell (2002) posit that human capital focuses on the uniqueness and value of human capital which drives towards the employment setting and configuration in the organisation. Uniqueness of human capital has been conceptualized as the degree of rareness and specialty, while strategic value refers the notion of exploiting market opportunities, diffusing potential threat which accelerates the efficiency and effectiveness of the firm (Barney, 1991). However, human capital approach asserts that the value and distinctiveness of knowledge are the most pertinent characteristics for innovation(Lepak \& Snell, 2002; Subramaniam $\&$ Youndt, 2005) which brings in high yields for the organisation, in turn expand the range of benefits to the customers (Lengnick-Hall \& Lengnick-Hall, 2003). From the innovation perspective, employees with valuable and unique knowledge and skills are competent with innovative capacity (Taggar, 2002). The employees who possess the innovative capacity are also submissive towards acquiring new skills that positively impacts firm's innovative performance (Cabello-Medina, López-Cabrales \& Valle-Cabrera, 2011). The uniqueness of knowledge has greater prominence in the domain of human capital as it facilitates the innovation capacity of the employees turning them to irreplaceable and idiosyncratic (Barney, 1991). It is foreseeable that such uniqueness of human capital generates differentiation which is the source of competitive advantages (Barney, 1991). In addition to the uniqueness and value of human capital, proactiveness has been also considered as part of human capital. Proactiveness represents the willingness to be engaged in audacious moves (Keh et al. 2007). The spirit of proactiveness remains in the anticipation of future demands and ability of firm to introduce new products to the market ahead of the competitors (Kreiser, Marino, Kuratko \& Weaver, 2013; Wang \& Altinay, 2012). However, proactiveness has been also regarded as one of the dimension of entrepreneurial orientation (Wang \& Altinay, 2012). As such, the organisational architecture that support innovativeness via entrepreneurial activities, as an internal climate factor, could help to foster innovative human capital (Alpkan et al., 2010). For instance, organisational architecture that is pro-innovative comprise of a suitable organisational setting that permit the entrepreneurs to access the organisational resources and conditions which help them to develop and implement innovative ideas (Raisch \& Birkinshaw, 2008).

Pro-innovativeness organisation architecture is facilitated by the organisational settings which are in favorable condition for employees to innovate. Previous literature purported that elements of organisational support such as allocation of free time, work discretion, rewards, and tolerance for risk taking have relationship with human capital (Alpkan et al., 2010). Literature highlighted that while supports are given, it will endeavor for resulting in competitive advantages (Hornsby 
et al., 2013). According to Alpkan et al. (2010), suitable organisational setting for intrapreneurial activities with the required support would generate required knowledge, skills to pursue for innovation.

Allocation of free time signifies to provide sufficient time for the persuasion for innovation (Hornsby et al., 2013) and implementing projects (Kuratko, Montagno \& Hornsby, 1990). Allocation of free time is a critical factor for entrepreneur in terms of their daily routines and intrapreneurial ideas and activities which encourages them to take risks in putting novel ideas to practice (Hornsby, Kuratko $\&$ Zahra, 2002). Availability of time denotes the sufficiency of time to actively develop valuable and unique ideas (Bamber, Owens, Davies \& Sulman, 2002). The previous studies revealed that pioneering steps to materialize innovative ideas is fostered by the spare time allotted to the concern entrepreneurs (Van den Ende, Wijnberg, Vogels \& Kerstens, 2003). The availability of free time would necessarily give scope to be actively involved in instilling valuable and unique knowledge and skills. Allocation of free time certainly pushes forward the employees to enthusiastically advance innovative activities (Hornsby et al., 2013). Thus, it can be hypothesised that:

H1.a-b-c Allocation of free time has a positive relationship with innovative human capital (uniqueness, value, and proactiveness)

Work discretion refers to delegating authority and providing decision making latitude (Hornsby et al., 2013) which concern the decision-making autonomy for managers in lower position and employees (Alpkan et al., 2010). According to Hornsby et al. (2002), work discretion facilitated entrepreneurs to make decisions regarding their work (Hornsby et al., 2002) in which they can implement their decision to realise their novel ideas. It has been asserted in the literature that work should be more knowledge-based and flexible to develop the ability to generate ideas, skills and acquire expertise (De Jong \& Den Hartog, 2007). By having autonomy, entrepreneurs can freely and proactively inculcate the valuable and unique knowledge which are regarded as human capital. Thus, it can be hypothesised that:

H2.a-b-c Work discretion has a positive relationship with innovative human capital (uniqueness, value, and proactiveness)

Rewards is considered as highlighting significant achievement and performance (Hornsby et al., 2002). Reward system of organisation bring a high level of trust for employees and give hope to employee that the organisational success benefit 
to all parties, and then both their commitment to innovation (Alpkan et al., 2010). A recent study by Coff and Kryscynski (2011) assumed to have linkage between intrinsic reward and human capital. Scholars have agreed upon the reality that the power of the value of human capital is mostly evident when reward system is in effect as part of organisational support (Lawler, 2000). When the entrepreneurs realise the appropriate reward, it is expected that they would proactively search for innovative ideas with the valuable and unique knowledge and skills. Thus, it can be hypothesised that:

H3.a-b-c Rewards has a positive relationship with innovative human capital (uniqueness, value, and proactiveness)

Tolerance to risk taking is another dimension of pro-innovativeness organisational architecture. Managers' risk tolerance is a situation when entrepreneurs are willing to take risks which may encourage them to be more innovative especially in turbulent markets (Hornsby et al., 2002). Entrepreneurs who have established the organisational setting to be pro-innovativeness, will be more tolerant while taking risk (Alpkan et al., 2010). According to Charyton, Snelbecker, Rahman \& Elliott (2013) tolerance of risk taking refers to the ability to formulate individual's ideas despite critical environmental setting. When the organisational architecture demonstrate a tolerable attitude towards taking risk, entrepreneurs do not hold any pressure to proactively come up with valuable and unique knowledge that build up the innovative human capital. Based on this, it can be hypothesised that:

\section{H4.a-b-c Tolerance to risk taking has a positive relationship with innovative human capital (uniqueness, value, and proactiveness)}

\section{Innovative Human Capital and Innovative Performance}

Human capital with tacit knowledge produces a competitive advantage through attributing the different performance in the firms (Hitt, Biermant, Shimizu \& Kochhar, 2001). The importance of human capital is noted in the literature which effect on firm's performance. Human capital should be viewed as the most valuable asset of an organisation and money spent to improve efficacy and productivity of human resource should be seen as an investment particularly for enterprises which relying on the staff's knowledge and skills (Petty \& Guthrie, 2000). In fact, human capital is seen as the most influential factors on innovative performance (Bantel \& Jackson, 1989). In this vein, human capital increases the ability of people to innovate (Lund Vinding, 2006) and consequently has a positive effect on innovative performance (Wu, Lin \& Hsu, 2007). 
Valuable and uniqueness of individual's knowledge, skills and abilities are the most relevant features for innovation (Subramaniam \& Youndt, 2005). This is because, there is a connection between the employees' knowledge and their ability to produce new products and services (Cabello-Medina et al., 2011). Unique employees' knowledge, skills, and abilities are called as rainmaker who contributes in developing innovative ideas and therefore products and services. Researchers highlighted that in the labor market, employee with rare knowledge, skills and abilities are not usually observed (Amar, 2002). Thus, this unique knowledge facilitate entrepreneurs to compete in the market which constitutes an intangible resource for firm innovation (Cabello-Medina et al., 2011).

On the other hand, firms can gain high returns in the market through valuable knowledge that enhance the ratio of benefits to customers (Lengnick-Hall \& Lengnick-Hall, 2003). Valuable human capital can enhance the firms' innovative performance (Cabello-Medina et al., 2011). In this manner, Blesa and Ripollés (2003) have observed entrepreneurial proactiveness as the firm's response to the opportunities within the market place. Entrepreneur, who behaves proactively, has an ability to predicate needs and observe competitors' action in market place. Proactiveness comprises taking initiative with efforts in shaping environment which leads performance (Blesa \& Ripollés, 2003). However, innovative performance can be achieved through (1) the introduction of a new good or a new quality of a good, (2) the introduction of a new method of production, including a new way of handling a commodity commercially, (3) the opening of a new market, and (4) the conquest of a new source of supply of raw material or intermediate input and the establishment of a new organisation (Schumpeter, 1984). In line with these arguments, it can be hypothesised that:

H5.a Uniqueness of human capital has a positive relationship with innovative performance

H5.b Value of human capital has a positive relationship with innovative performance

H5.c Proactiveness of human capital has a positive relationship with innovative performance

\section{Mediating Effect of Innovative Human Capital}

Human capital which is formed by the knowledge, skills, and abilities can contribute to the organisational competencies and performance (Hayton \& Kelley, 2006). Besides that, human capital may also apply an instrumental role in the attempts to shape a suitable internal support environment to increase organisational innovative 
performance (Bantel \& Jackson, 1989; Wu et al., 2007). A suitable organisational setting for entrepreneurial activities with the required support has proposed to have an effect on innovative human capital in terms of generating required knowledge, skills to pursue for innovation (Alpkan et al., 2010).

However, past studies emphasise the positive impact of mediating role of human capital. For instance, Zhu, Chew \& Spangler, (2005) posit that human capital mediates the relationship between leadership and organisational outcome. Therefore, there is a high chance for innovative human capital to play a similar mediating role in the relationship between organisational support and innovative performance. Therefore, higher organisational supports in terms of allocation for free time, work discretion, rewards, and tolerance for risk taking would create a better climate for innovativeness. In other words, entrepreneurs who are reinforced through allocation for free time, work discretion, rewards, and tolerance for risk taking, may experience high level of innovative performance. Thus, it is worth to test the following hypothesis:

H6.a-1 Innovative human capital (uniqueness, value, and proactiveness) mediate the relationship between proinnovativeness organisation architecture (allocation for free time, work discretion, rewards, and tolerance for risk taking) and innovative performance.

Based on the above discussion, Figure 1 shows the research model integrating the pro- innovativeness organisation architecture dimensions, innovative human capital dimensions and innovative performance variable in a testable manner.

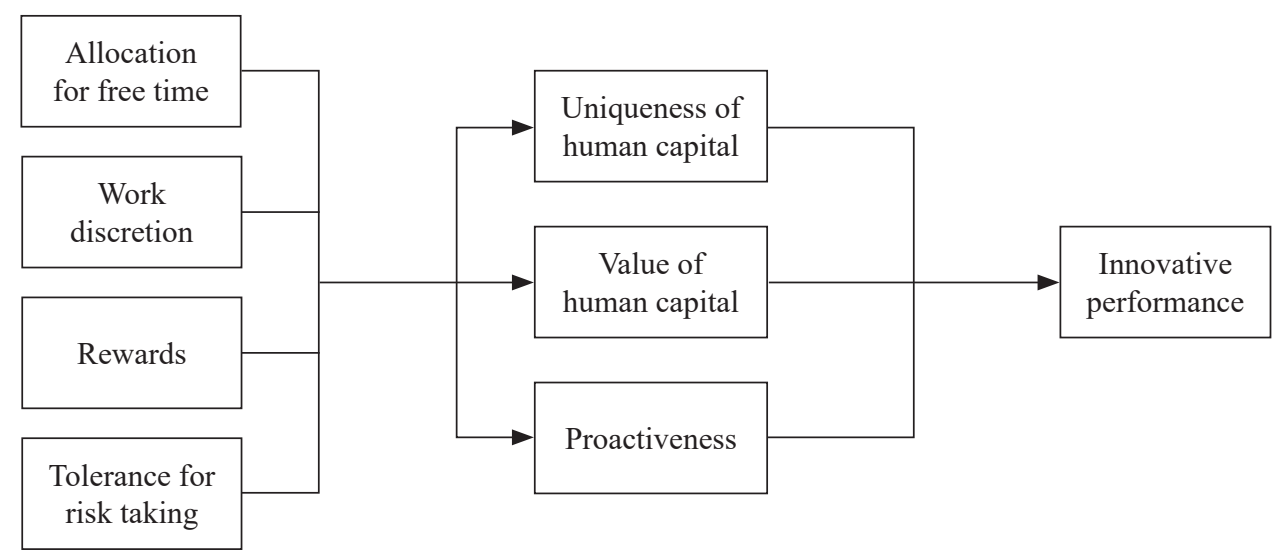

Figure 1. Research framework 


\section{METHODOLOGY}

In this study, a structured study instrument was used for data collection purpose. The questionnaires were administered through drop-offs and pickups. The study utilised Peninsular Malaysia Small and Medium Enterprises Directory 2011/12 as its sampling frame. A total of 1000 active SMEs were selected via simple random sampling. A total of 263 SMEs (response rate $=26 \%$ ) responded to the questionnaire. However, a total of 262 usable questionnaires were thus secured for analysis. The respondents' company has been established since year 1929 to 2013. Majority of the respondents are from the services sector $(45 \%)$ followed by manufacturing and agriculture with $30.5 \%$ and $5.7 \%$ respectively. The market of their business mostly is local ( $85.1 \%) .68 .3 \%$ are the owner of the business. Sole proprietorship formed the majority of the respondents' company $(64.5 \%)$ followed partnership (22.5\%) and joint venture $(5.7 \%)$ and others. In relation to the total numbers of employees, $63.4 \%$ of the respondents reported that they have less than 5 employees, $28.2 \%$ with 6-20 employees and $8.4 \%$ respondents with more than 21 employees. Their education level started from high school (20\%), certificate (14.1\%), diploma (28.6\%), degree (23.7\%), and master (2.3\%).

Multi-item scales were used to measure pro-innovativeness organisation architecture, social embeddeness, and innovative human capital. A 5-point Likert scales $(1=$ strongly disagree to $5=$ strongly agree $)$ were used to measure the level of respondents' agreeableness on the statement posed to them. A questionnaire was developed from past studied. Pro-innovativeness organisation architecture has four dimensions; allocation of frees time (3-items), work discretion (3-items), rewards (4-items), and tolerance for risk taking (3-items) which are adapted from Alpkan et al. (2010). Innovation human capital has three dimensions; uniqueness of human capital (4-items), value of human capital (5-items), which are adapted from Cabello-Medina et al. (2011) and proactiveness (2-items) which is adapted from Blesa and Ripollés (2003). Innovation performance is measured by 6-items, which is adapted from Johannessen, Dolva \& Kolvereid, (1997).

Partial Least Squares (PLS) structural equation modeling (SEM) were applied to estimate the measurement and structural model of this study using the software application SmartPLS 2.0 (Ringle \& Wende, 2005). The results were presented in three steps. Firstly, the Harman single factor test was performed to test the existence of common method bias in the study. Secondly, the results of the measurement model were assessed and discussed. Thirdly, the results of hypothesis hypothesised in this study were assessed through the examination of the structural model. 
In this study, at first, the existence of common method bias was examined using the Harman's single factor test suggested by (Podsakoff, MacKenzie, Lee \& Podsakoff, 2003; Podsakoff \& Organ, 1986). The result shows that the first factor captured $24.964 \%$ of the variance in the data which is less than threshold level of $50 \%$ of total variance explained. The quality of the measurement model was assessed by examining convergent validity includes factor loading, average variance extracted (AVE), composite reliability (CR) as well as discriminant validity suggested by Hair, Ringle \& Sarstedt, (2011) as a rule of thumb for model evaluation. Results show that indicator loadings for all items exceeded the recommended value of 0.7 (Hair, Black, Babin \& Anderson, 2009). AVE were in the range of 0.575 and 0.803 , which is above the recommended value of 0.5 , and CR ranged from 0.858 to 0.904 which exceeded the recommended value of 0.7 (Hair et al., 2009). The results are shown in Table 1.

The discriminant validity of the measurement items was tested through the criteria suggested by Fornell and Larcker (1981). Table 2 depict the discriminant validity of this study and showed that the all the square root of AVEs, shown in the elements in the matrix diagonals are higher in all cases in the off-diagonal elements in their corresponding row and column, hence establishing the discriminant validity.

Path analysis was performed to evaluate the structural model. The primary evaluation criteria for structural model are the $\mathrm{R}^{2}$ values and the level and significance of the path coefficients (Hair et al., 2011). The $\mathrm{R}^{2}$ of uniqueness of human capital is 0.114 , value of human capital is 0.163 , proactiveness is 0.164 , and innovative performance is 0.112 (Figure 2). The study hypothesised that four dimensions of pro-innovativeness organisation architecture (allocation for free time, work discretion, rewards and tolerance for risk taking) have the relationship with three dimensions of innovative human capital in terms of uniqueness, value, and proactiveness. The results showed that rewards has a significant relationship with uniqueness of human capital $(\beta=0.191, p<0.01)$, value of human capital $(\beta=0.320, p<0.01)$, and proactiveness $(\beta=0.244, p<0.01)$. Furthermore, tolerance for risk taking has a positive influence on uniqueness of human capital $(\beta=0.179$, $p<0.01$ ), value of human capital $(\beta=0.135, p<0.05)$, and proactiveness $(\beta=0.193$, $p<0.01)$. The relationship between three dimensions of innovative human capital in terms of uniqueness, value, and proactiveness with innovative performance has been tested. The finding revealed that uniqueness of human capital has significant relationship with innovative performance with $\beta=0.296, p<0.01$ ). Table 3 shows the results of direct effects. 
Table 1

Results of measurement model

\begin{tabular}{|c|c|c|c|c|c|}
\hline Constructs & Variables & Items & Loading & AVE & $\mathrm{CR}$ \\
\hline \multirow[t]{12}{*}{ Pro-innovativeness } & \multirow[t]{3}{*}{ Allocation of Free Time } & AFT1 & 0.814 & \multirow[t]{3}{*}{0.668} & \multirow[t]{3}{*}{0.858} \\
\hline & & AFT2 & 0.790 & & \\
\hline & & AFT3 & 0.848 & & \\
\hline & \multirow[t]{3}{*}{ Work Discretion } & WD1 & 0.885 & \multirow[t]{3}{*}{0.759} & \multirow[t]{3}{*}{0.904} \\
\hline & & WD2 & 0.880 & & \\
\hline & & WD3 & 0.848 & & \\
\hline & \multirow[t]{4}{*}{ Rewards } & REW1 & 0.798 & \multirow[t]{4}{*}{0.672} & \multirow[t]{4}{*}{0.891} \\
\hline & & REW2 & 0.800 & & \\
\hline & & REW3 & 0.896 & & \\
\hline & & REW4 & 0.780 & & \\
\hline & \multirow[t]{2}{*}{ Tolerance for Risk Taking } & TRT2 & 0.875 & \multirow[t]{2}{*}{0.803} & \multirow[t]{2}{*}{0.891} \\
\hline & & TRT3 & 0.917 & & \\
\hline \multirow{17}{*}{$\begin{array}{l}\text { Innovative Human } \\
\text { Capital }\end{array}$} & \multirow{4}{*}{$\begin{array}{l}\text { Uniqueness of Human } \\
\text { Capital }\end{array}$} & UHC1 & 0.769 & \multirow[t]{4}{*}{0.641} & \multirow[t]{4}{*}{0.877} \\
\hline & & UHC2 & 0.789 & & \\
\hline & & UHC3 & 0.837 & & \\
\hline & & UHC4 & 0.806 & & \\
\hline & \multirow[t]{5}{*}{ Value of Human Capital } & VHC1 & 0.816 & \multirow[t]{5}{*}{0.634} & \multirow[t]{5}{*}{0.897} \\
\hline & & VHC2 & 0.789 & & \\
\hline & & VHC3 & 0.803 & & \\
\hline & & VHC4 & 0.812 & & \\
\hline & & VHC5 & 0.760 & & \\
\hline & \multirow[t]{2}{*}{ Proactiveness } & PROAC1 & 0.905 & \multirow[t]{2}{*}{0.753} & \multirow[t]{2}{*}{0.859} \\
\hline & & PROAC2 & 0.829 & & \\
\hline & \multirow[t]{6}{*}{ Innovative performance } & IP1 & 0.824 & \multirow[t]{6}{*}{0.575} & \multirow[t]{6}{*}{0.890} \\
\hline & & IP2 & 0.759 & & \\
\hline & & IP3 & 0.754 & & \\
\hline & & IP4 & 0.705 & & \\
\hline & & IP5 & 0.791 & & \\
\hline & & IP6 & 0.711 & & \\
\hline
\end{tabular}

$\mathrm{AVE}=$ Average variance extracted; $\mathrm{CR}=$ Composite reliability; One item was deleted (TRT1) 
Table 2

Discriminant validity of constructs

\begin{tabular}{lcccccccr}
\hline & AFT & IP & PRO & REW & TRT & UHC & VHC & WD \\
\hline AFT & 0.817 & & & & & & & \\
IP & 0.053 & 0.758 & & & & & & \\
PRO & 0.159 & 0.220 & $\mathbf{0 . 8 6 8}$ & & & & & \\
REW & 0.416 & 0.104 & 0.358 & 0.820 & & & & \\
TRT & 0.245 & 0.057 & 0.325 & 0.461 & $\mathbf{0 . 8 9 6}$ & & & \\
UHC & 0.132 & 0.330 & 0.535 & 0.291 & 0.281 & 0.801 & & \\
VHC & 0.197 & 0.224 & 0.538 & 0.383 & 0.280 & 0.640 & $\mathbf{0 . 7 9 6}$ & \\
WD & 0.462 & 0.036 & 0.245 & 0.473 & 0.346 & 0.195 & 0.177 & 0.871 \\
\hline
\end{tabular}

Diagonals (in bold) represent the square root of average variance extracted while the other entries represent the squared correlations. AFT $=$ Allocation of free time; $\mathrm{IP}=$ Innovative performance; Proact $=$ Proactiveness; $\mathrm{REW}=$ Rewards; $\mathrm{TRT}=$ Tolerance for risk taking; $\mathrm{UHC}=$ Uniqueness of human capital; $\mathrm{VHC}=$ Value of human capital; $\mathrm{WD}=$ Work discretion

Table 3

Result of Direct Effects

\begin{tabular}{cccccc}
\hline Hypothesis & Path & Beta & SE & $t$-value & Decision \\
\hline H1.a & AFT -> UHC & -0.014 & 0.073 & 0.187 & Not Supported \\
H1.b & AFT -> VHC & 0.052 & 0.074 & 0.695 & Not Supported \\
H1.c & AFT -> PRO & -0.025 & 0.062 & 0.398 & Not Supported \\
H2.a & WD -> UHC & 0.049 & 0.095 & 0.510 & Not Supported \\
H2.b & WD -> VHC & -0.045 & 0.076 & 0.597 & Not Supported \\
H2.c & WD -> PRO & 0.075 & 0.074 & 1.007 & Not Supported \\
H3.a & REW -> UHC & 0.191 & 0.080 & $2.397^{* *}$ & Supported \\
H3.b & REW -> VHC & 0.320 & 0.066 & $4.866^{* *}$ & Supported \\
H3.c & REW -> PRO & 0.244 & 0.077 & $3.185^{* *}$ & Supported \\
H4.a & TRT -> UHC & 0.179 & 0.067 & $2.691^{* *}$ & Supported \\
H4.b & TRT -> VHC & 0.135 & 0.071 & $1.892^{*}$ & Supported \\
H4.c & TRT -> PRO & 0.193 & 0.070 & $2.750^{* *}$ & Supported \\
H5.a & UHC -> IP & 0.296 & 0.082 & $3.628^{* *}$ & Supported \\
H5.b & VHC -> IP & 0.001 & 0.104 & 0.014 & Not Supported \\
H5.c & PRO -> IP & 0.061 & 0.078 & 0.786 & Not Supported \\
\hline
\end{tabular}

${ }^{*} p<0.05,{ }^{*} p<0.01, \mathrm{AFT}=$ Allocation of free time; WD= Work discretion; REW; Rewards; TRT= Tolerance for risk taking; $\mathrm{UHC}=$ Uniqueness of human capital; $\mathrm{VHC}=$ Value of human capital; Proact= Proactiveness; $\mathrm{IP}=$ Innovative performance 
Mediating effect of innovative human capital dimensions (uniqueness, value, and proactiveness) on the relationship between pro-innovativeness organisation architecture dimensions (allocation for free time, work discretion, rewards and tolerance for risk taking) and innovative performance has been tested (Table 4). Following the approach of Preacher and Hayes (2008), the results shows that the uniqueness of human capital mediates on the relationship between tolerance of risk taking and innovative performance $(t$-value $=2.119, p<0.05)$.

Table 4

Results of Mediating Effects

\begin{tabular}{|c|c|c|c|c|c|c|c|c|c|}
\hline \multirow{2}{*}{ Path } & \multirow{2}{*}{ Hypothesis } & \multirow{2}{*}{ Path a } & \multirow{2}{*}{ Path b } & \multirow{2}{*}{$\begin{array}{c}\text { Indirect } \\
\text { Effect }\end{array}$} & \multirow[t]{2}{*}{ SE } & \multirow[t]{2}{*}{$\mathrm{t}$-value } & \multirow{2}{*}{ Decision } & \multicolumn{2}{|c|}{$\begin{array}{c}\text { Bootstrapped } \\
\text { Confidence Interval }\end{array}$} \\
\hline & & & & & & & & $95 \% \mathrm{LL}$ & $95 \%$ UL \\
\hline AFT-UHC-IP & H6.a & -0.014 & 0.296 & -0.004 & 0.023 & -0.180 & Not supported & -0.049 & 0.041 \\
\hline AFT-VHC-IP & H6.b & 0.052 & 0.001 & 0.000 & 0.011 & 0.005 & Not supported & -0.022 & 0.022 \\
\hline AFT-PRO-IP & H6.c & -0.025 & 0.061 & -0.002 & 0.006 & -0.254 & Not supported & -0.013 & 0.010 \\
\hline WD-UHC-IP & H6.d & 0.049 & 0.296 & 0.015 & 0.031 & 0.468 & Not supported & -0.046 & 0.075 \\
\hline WD-VHC-IP & H6.e & -0.045 & 0.001 & 0.000 & 0.010 & -0.005 & Not supported & -0.020 & 0.020 \\
\hline WD-PRO-IP & H6.f & 0.075 & 0.061 & 0.005 & 0.009 & 0.508 & Not supported & -0.013 & 0.022 \\
\hline REW-UHC-IP & H6.g & 0.191 & 0.296 & 0.057 & 0.029 & 1.950 & Not Supported & 0.000 & 0.113 \\
\hline REW-VHC-IP & H6.h & 0.320 & 0.001 & 0.000 & 0.034 & 0.009 & Not supported & -0.066 & 0.067 \\
\hline REW-PRO-IP & H6.i & 0.244 & 0.061 & 0.015 & 0.020 & 0.744 & Not supported & -0.024 & 0.054 \\
\hline TRT-UHC-IP & H6.j & 0.179 & 0.296 & 0.053 & 0.025 & $2.119 *$ & Supported & 0.004 & 0.102 \\
\hline TRT-VHC-IP & H6.k & 0.135 & 0.001 & 0.000 & 0.016 & 0.008 & Not supported & -0.031 & 0.031 \\
\hline TRT-PRO-IP & H6.1 & 0.193 & 0.061 & 0.012 & 0.016 & 0.736 & Not supported & -0.020 & 0.043 \\
\hline
\end{tabular}

${ }^{*} p<0.05, \mathrm{AFT}=$ Allocation of free time; $\mathrm{WD}=$ Work discretion; REW; Rewards; TRT= Tolerance for risk taking; UHC $=\mathrm{Uniqueness}$ of human capital; $\mathrm{VHC}=$ Value of human capital; Proact $=$ Proactiveness; $\mathrm{IP}=$ innovation performance

Table 5 showed the summary of the predictive relevance for the endogenous construct under consideration in this research. The result showed that all exogenous constructs in this research have predictive relevance as all the values are above 0 .

Table 5

The result of the $Q^{2}$ values

\begin{tabular}{lcc}
\hline Endogens variables & $\mathrm{Q}^{2}$ & $\mathrm{R}^{2}$ \\
\hline Uniqueness of human capital & 0.072 & 0.114 \\
Value of human capital & 0.093 & 0.163 \\
Proactiveness & 0.125 & 0.164 \\
Innovative performance & 0.060 & 0.112 \\
\hline
\end{tabular}




\section{DISCUSSIONS AND MANAGERIAL IMPLICATION}

This study investigates on how to capture the 'pioneering minds' of the SMEs via looking at the innovative human capital. In turns, this study analysed the factors that could cultivate 'pioneering minds' and its impact on innovative performance. The mediating role of human capital (in terms of uniqueness, value, and proactiveness) was tested on the relationship between pro-innovativeness organisation architecture (in terms of allocation for free times, work discretion, rewards, and tolerance for risk taking) and innovative performance in the context of Malaysian SMEs. The finding showed that rewards have an impact with all three dimensions of innovative human capital namely uniqueness of human capital, value of human capital, and proactiveness. This result indicates that reward is crucial in encouraging 'pioneering mind' among the entrepreneurs and this may foster them to improve their works to be unique as compared to their competitors. Continuing rewards system can encourage the entrepreneurs to consistently build new ideas and foster creativity as well as commitment towards innovation (Alpkan et al., 2010). Further, the power of the value of human capital is increased when reward system is in effect as part of organisational support (Lawler, 2000). The findings also signify that tolerance for risk taking has positive influence on uniqueness of human capital, value of human capital, and proactiveness. The term 'risk taker' can be considered as a positive attribute for the entrepreneurs. Here, the entrepreneurs have the willingness to take risks which eventually could inspire them to be more creative and innovative (Gupta, MacMillan \& Surie, 2004).

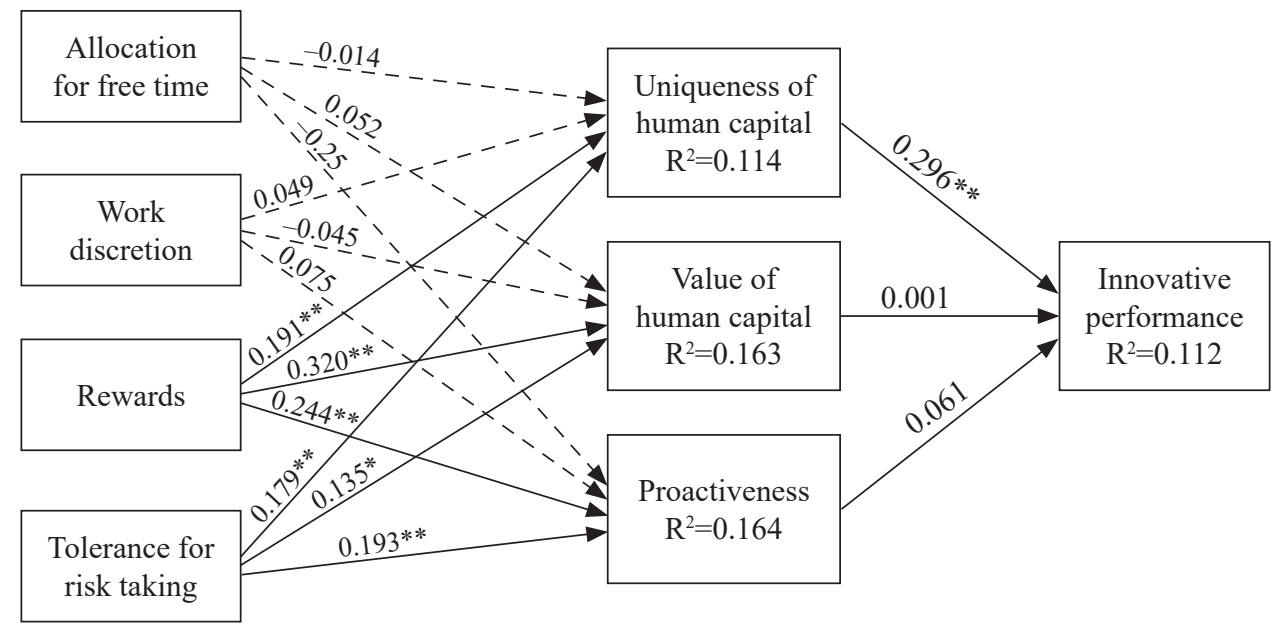

Figure 2. Structural model ${ }^{*} p<0.05,{ }^{* *} p<0.01$ 
Moreover, when the organisational climate demonstrate a tolerable attitude towards taking risk, entrepreneurs proactively can come up with valuable and unique knowledge resulting in building up the innovative human capital.

In the relationship between three variables of innovative human capital namely uniqueness, value, and proactiveness with innovative performance, the results indicated that only the uniqueness of human capital has a significant relationship with innovative performance. This is consistent with the previous study in which uniqueness of individual's knowledge, skills and abilities is considered as one of the most relevant features for innovation (Subramaniam \& Youndt, 2005). It can be said that there is a connection between capturing the 'pioneering mind' and their ability to produce new products. Having 'pioneering mind' with the elements of uniqueness, valuable and proactiveness could contribute in establishing innovative ideas and hence may facilitate the firms to compete aggressively in the market. Consequently, the linkage between tolerance for risk taking and innovative performance can be strengthening if uniqueness of human capital plays an intervening role in Malaysian SMEs. A suitable tolerance for entrapreneurial risk taking may assist the entrepreneurs to generate required knowledge, skills which lead for superior new ideas and enhance innovative performance.

In terms of managerial implication, it is possible to suggest that SMEs should put more focus on their reward system and tolerance for risk taking in order to encourage and enhance the 'pioneering mind' which in turn may increase innovative performance. They should try to establish an internal climate, where especially reward system and tolerance for risk taking are extraordinary. Such a climate is presumably able to capture the 'pioneering mind' among the entrepreneurs which may help the SMEs to generate new ideas in the development of new product, method, and market.

\section{LIMITATION AND FUTURE RESEARCH}

The main limitation of the study was its reliance on single respondents (the owner of SMEs). In this manner, Podsakoff \& Organ (1986) have posited that survey data based on self-reports may be subject to social desirability bias in which there is a potential that responding SMEs would agree more on socially desirable answers rather than truthfully express their honest feelings and opinions. Although the use of a single respondent is not ideal, it has been the method of choice for many researchers. Nevertheless, an assurance of anonymity can reduce such bias and common method bias using Harman's one-factor test were conducted and none 
seemed to be present (Podsakoff \& Organ, 1986; Scott \& Bruce, 1994). Besides, questionnaire length might limit the ability to explore the influence of a potentially important determinant of the pioneering minds. Hence future research can build on the significant factors in this research by introducing new factors and measures to provide new insights and extend the model. As the influence of value of human capital and proactiveness on innovative performance is not significant in the current study, future research may consider moderating variable to strengthen these relationships. Finally, the study is limited by its cross-sectional design. Although most plausible directions for the pathways in the framework had been performed, longitudinal research is desirable to examine the direction of causality of the relationships and to detect possible reciprocal processes.

\section{CONCLUSIONS}

In conclusion, the concept of human capital is very essential in enhancing the innovative performance. To this end, an entrepreneur would be equipped with the right types of pro-innovativeness architecture namely rewards and tolerance for risk taking to effectively generate and implement new, innovative and unique knowledge. However, innovation will only flourish by having uniqueness human capital among SMEs. Managing innovation is about nurturing and developing human capital in which new ideas are generated, valued and supported and achieving such an "innovation performance" status is not an easy task without a proper road map or strategies being outlined and put into practice.

\section{ACKNOWLEDGEMENT}

We would like to thank the University Sains Malaysia for funding this project under the Research University Grant - 1001/PMGT/816236

\section{REFERENCES}

Abdul Halim, H., Ahmad, N. H., Ramayah, T., \& Taghizadeh, S. K. (2014). The quest for innovative human capital: The effects of pro-innovativeness architecture and social embeddedness. Australian Journal of Basic and Applied Sciences, 8(12), 93-103.

Alegre, J., Lapiedra, R., \& Chiva, R. (2006). A measurement scale for product innovation performance. European Journal of Innovation Management, 9(4), 333-346. http://dx.doi.org/10.1108/14601060610707812 
Alpkan, L., Bulut, C., Gunday, G., Ulusoy, G., \& Kilic, K. (2010). Organizational support for intrapreneurship and its interaction with human capital to enhance innovative performance. Management Decision, 48(5), 732-755. http://dx.doi. org/10.1108/00251741011043902

Amar, A. D. (2002). Managing knowledge workers: Unleashing innovation and productivity: Greenwood Publishing Group.

Bamber, D., Owens, J., Davies, J., \& Sulman, A. (2002). Enabling the emergent entrepreneurial organization to develop new products. International Journal of Entrepreneurial Behaviour \& Research, 8(20), 203-221. http://dx.doi.org/ $10.1108 / 13552550210436530$

Bantel, K. A., \& Jackson, S. E. (1989). Top management and innovations in banking: does the composition of the top team make a difference? Strategic Management Journal, 10(S1), 107-124. http://dx.doi.org/10.1002/smj.4250100709

Barney, J. (1991). Firm resources and sustained competitive advantage. Journal of management, 17(1), 99-120. http://dx.doi.org/10.1177/014920639101700108

Blesa, A., \& Ripollés, M. (2003). The role of market orientation in the relationship between entrepreneurial proactiveness and performance. Journal of Entrepreneurship, 12(1), 1-19. http://dx.doi.org/10.1177/097135570301200101

Cabello-Medina, C., López-Cabrales, Á., \& Valle-Cabrera, R. (2011). Leveraging the innovative performance of human capital through HRM and social capital in Spanish firms. The International Journal of Human Resource Management, 22(04), 807-828. http://dx.doi.org/10.1080/09585192.2011.555125

Charyton, C., Snelbecker, G. E., Rahman, M. A., \& Elliott, J. O. (2013). College Students' Creative Attributes as a Predictor of Cognitive Risk Tolerance.

Coff, R., \& Kryscynski, D. (2011). Invited editorial: drilling for micro-foundations of human capital-based competitive advantages. Journal of Management, 37(5), 1429-1443. http://dx.doi.org/10.1177/0149206310397772

De Jong, J. P., \& Den Hartog, D. N. (2007). How leaders influence employees' innovative behaviour. European Journal of innovation management, 10(1), 41-64. http:// dx.doi.org/10.1108/14601060710720546

Eleventh Malaysia Plan (2016-2020). Economic Planning Unit. Retrieved January 8, 2015 from http://rmk11.epu.gov.my/index.php/en/.

Fahy, J. (2000). The resource-based view of the firm: some stumbling-blocks on the road to understanding sustainable competitive advantage. Journal of European industrial training, 24(2/3/4), 94-104.

Eleventh Malaysia Plan (2016-2020). Economic Planning Unit. Retrieved from http:// rmk11.epu.gov.my/index.php/en/.http://dx.doi.org/10.1108/03090590010321061

Fornell, C., \& Larcker, D. F. (1981). Evaluating structural equation models with unobservable variables and measurement error. Journal of Marketing Research, 18(1), 39-50. http://dx.doi.org/10.2307/3151312

Gupta, V., MacMillan, I. C., \& Surie, G. (2004). Entrepreneurial leadership: Developing and measuring a cross-cultural construct. Journal of Business Venturing, 19(2), 241-260.

Hair, J. F., Black, W. C., Babin, B. J., \& Anderson, R. E. (2009). Multivariate Data Analysis. Upper Saddle, New Jersey: Pearson Prentice Hall. 
Hair, J. F., Ringle, C. M., \& Sarstedt, M. (2011). PLS-SEM: Indeed a silver bullet. The Journal of Marketing Theory and Practice, 19(2), 139-152. http://dx.doi. org/10.2753/MTP1069-6679190202

Hayton, J. C., \& Kelley, D. J. (2006). A competency-based framework for promoting corporate entrepreneurship. Human Resource Management, 45(3), 407-427. http://dx.doi.org/10.1002/hrm.20118

Henri, J.-F. (2006). Management control systems and strategy: A resource-based perspective. Accounting, Organizations and Society, 31(6), 529-558. http://dx. doi.org/10.1016/j.aos.2005.07.001

Hitt, M. A., Biermant, L., Shimizu, K., \& Kochhar, R. (2001). Direct and moderating effects of human capital on strategy and performance in professional service firms: A resource-based perspective. Academy of Management Journal, 44(1), 13-28. http://dx.doi.org/10.2307/3069334

Hornsby, J. S., Kuratko, D. F., Holt, D. T., \& Wales, W. J. (2013). Assessing a measurement of organizational preparedness for corporate entrepreneurship. Journal of Product Innovation Management, 30(5), 937-955. http://dx.doi.org/10.1111/jpim.12038

Hornsby, J. S., Kuratko, D. F., \& Zahra, S. A. (2002). Middle managers' perception of the internal environment for corporate entrepreneurship: assessing a measurement scale. Journal of Business Venturing, 17(3), 253-273. http://dx.doi.org/10.1016/ S0883-9026(00)00059-8

Jeong, I., Pae, J. H., \& Zhou, D. (2006). Antecedents and consequences of the strategic orientations in new product development: The case of Chinese manufacturers. Industrial Marketing Management, 35(3), 348-358. http://dx.doi.org/10.1016/j. indmarman.2005.06.010

Johannessen, J.-A., Dolva, J., \& Kolvereid, L. (1997). Perceived innovation success in the Russian market. International Journal of Information Management, 17(1), 13-20. http://dx.doi.org/10.1016/S0268-4012(96)00039-4

Keh, H. T., Nguyen, T. T. M., \& Ng, H. P. (2007). The effects of entrepreneurial orientation and marketing information on the performance of SMEs. Journal of Business Venturing, 22(4), 592-611. http://dx.doi.org/10.1016/j.jbusvent.2006.05.003

Kreiser, P. M., Marino, L. D., Kuratko, D. F., \& Weaver, K. M. (2013). Disaggregating entrepreneurial orientation: the non-linear impact of innovativeness, proactiveness and risk-taking on SME performance. Small Business Economics, 40(2), 273291. http://dx.doi.org/10.1007/s11187-012-9460-x

Kuratko, D., Montagno, R. V., \& Hornsby, J. (1990). Developing an intrapreneurial assessment instrument for an effective corporate entrepreneurial environment. Strategic Management Journal, 11, 49-58.

Kuratko, D. F., Ireland, R. D., Covin, J. G., \& Hornsby, J. S. (2005). A model of middlelevel managers' entrepreneurial behavior. Entrepreneurship Theory and Practice, 29(6), 699-716. http://dx.doi.org/10.1111/j.1540-6520.2005.00104.x

Lawler, E. E. (2000). Rewarding excellence (Vol. 13). Jossey-Bass San Francisco.

Lengnick-Hall, M. L., \& Lengnick-Hall, C. A. (2003). HR's role in building relationship networks. The Academy of Management Executive, 17(4), 53-63. http://dx.doi. org/10.5465/AME.2003.11851841 
Lepak, D. P., \& Snell, S. A. (2002). Examining the human resource architecture: The relationships among human capital, employment, and human resource configurations. Journal of Management, 28(4), 517-543. http://dx.doi. org/10.1177/014920630202800403

Lund Vinding, A. (2006). Absorptive capacity and innovative performance: A human capital approach. Economics of Innovation and New Technology, 15(4-5), 507517. http://dx.doi.org/10.1080/10438590500513057

Martin, B. C., McNally, J. J., \& Kay, M. J. (2013). Examining the formation of human capital in entrepreneurship: A meta-analysis of entrepreneurship education outcomes. Journal of Business Venturing, 28(2), 211-224. http://dx.doi.org/10.1016/j. jbusvent.2012.03.002

Miciunas, G. (2003). What makes for effective organisational architecture in corporate real estate? Going beyond reporting structure and sourcing decisions to considering strategic design issues. Journal of Corporate Real Estate, 5(1), 19-30. http://dx.doi.org/10.1108/14630010310811975

Minh, T.T., \& Hjortsø, C.N. (2015). How institutions influence SME innovation and networking practices: The case of Vietnamese agribusiness. Journal of Small Business Management 53(S1), 209-228. http://dx.doi.org/10.1111/jsbm.12189

MOSTI. (2010). from http://www.mosti.gov.my/

National Economic Advisory. (2010). Economic Transformation Programme Report. Retrieved September 2011 from http://www.neac.gov.my/node/80

Petty, R., \& Guthrie, J. (2000). Intellectual capital literature review: Measurement, reporting and management. Journal of intellectual capital, 1(2), 155-176. http://dx.doi.org/10.1108/14691930010348731

Ployhart, R. E., \& Moliterno, T. P. (2011). Emergence of the human capital resource: A multilevel model. Academy of Management Review, 36(1), 127-150. http://dx.doi.org/10.5465/amr.2009.0318

Podsakoff, P. M., MacKenzie, S. B., Lee, J.-Y., \& Podsakoff, N. P. (2003). Common method biases in behavioral research: a critical review of the literature and recommended remedies. Journal of applied psychology, 88(5), 879-903. http://dx.doi.org/10.1037/0021-9010.88.5.879

Podsakoff, P. M., \& Organ, D. W. (1986). Self-reports in organizational research: Problems and prospects. Journal of management, 12(4), 531-544. http://dx.doi. org/10.1177/014920638601200408

Preacher, K. J., \& Hayes, A. F. (2008). Asymptotic and resampling strategies for assessing and comparing indirect effects in multiple mediator models. Behavior research methods, 40(3), 879-891. http://dx.doi.org/10.3758/BRM.40.3.879

Raisch, S., \& Birkinshaw, J. (2008). Organizational ambidexterity: Antecedents, outcomes, and moderators. Journal of Management, 34(3), 375-409. http://dx.doi. org/10.1177/0149206308316058

Ramayah, T., Ling, N. S., Taghizadeh, S. K., \& Rahman, S. A. (2016). Factors influencing SMEs website continuance intention in Malaysia. Telematics and Informatics, 33(1), 150-164. http://dx.doi.org/10.1016/j.tele.2015.06.007

Ringle, C., \& Wende, Will. (2005). SmartPLS. Retrieved from http://www.smartpls.de 
Saleh, A. S., \& Ndubisi, N. O. (2006). An evaluation of SME development in Malaysia. Int. Rev. Bus. Res. Pap., 2(1), 1-14.

Schumpeter, J. A. (1984). The theory of economic development: An inquiry into profits, capital, credit, interest, and the business cycle (Vol. 55): Transaction Publishers.

Scott, S. G., \& Bruce, R. A. (1994). Determinants of innovative behavior: A path model of individual innovation in the workplace. Academy of Management Journal, 37(3), 580-607. http://dx.doi.org/10.2307/256701

SME Crop. (2015). SME development framework: The Malaysian case. http://www.cbe. org.eg/NR/rdonlyres/95EA10FA-62EE-4469-A40E-A952FDE2B434/2737/ CairoSMEConferenceJan2015Session3DatoHafsahMalaysi.pdf

Subramaniam, M., \& Youndt, M. A. (2005). The influence of intellectual capital on the types of innovative capabilities. Academy of Management Journal, 48(3), 450463. http://dx.doi.org/10.5465/AMJ.2005.17407911

Taggar, S. (2002). Individual creativity and group ability to utilize individual creative resources: A multilevel model. Academy of Management Journal, 45(2), 315330. http://dx.doi.org/10.2307/3069349

Teece, D. J., Pisano, G., \& Shuen, A. (1997). Dynamic capabilities and strategic management. Strategic Management Journal, 18(7), 509-533. http://dx.doi. org/10.1002/(SICI)1097-0266(199708)18:7<509::AID-SMJ882>3.0.CO;2-Z

Van den Ende, J., Wijnberg, N., Vogels, R., \& Kerstens, M. (2003). Organizing innovative projects to interact with market dynamics: A coevolutionary approach. European Management Journal, 21(3), 273-284.

Wang, C. L., \& Altinay, L. (2012). Social embeddedness, entrepreneurial orientation and firm growth in ethnic minority small businesses in the UK. International Small Business Journal, 30(1), 3-23. http://dx.doi.org/10.1016/s0263-2373(03)00051-3

Wernerfelt, B. (2014). On the role of the RBV in marketing. Journal of the Academy of Marketing Science, 42(1), 22-23. http://dx.doi.org/10.1007/s11747-013-0335-8

World Economic Forum. (2015). Global Competitiveness Index. from http://www. weforum.org/

Wu, S.-H., Lin, L.-Y., \& Hsu, M.-Y. (2007). Intellectual capital, dynamic capabilities and innovative performance of organisations. International Journal of Technology Management, 39(3), 279-296. http://dx.doi.org/10.1504/IJTM.2007.013496

Yeoh, P.-L., (2014). Internationalization and performance outcomes of entrepreneurial family SMEs: the role of outside CEOs, technology sourcing, and innovation. Thunderbird International Business Review, 56(1), 77-96. http://dx.doi.org/ 10.1002/tie. 21597

Zhu, W., Chew, I. K., \& Spangler, W. D. (2005). CEO transformational leadership and organizational outcomes: The mediating role of human-capital-enhancing human resource management. The Leadership Quarterly, 16(1), 39-52. http://dx.doi. org/10.1016/j.leaqua.2004.06.001 